УДК 372.2/.3.015.31:070](477)

DOI:

Ірина Кузьма, кандидат педагогічних наук, викладач кафедри педагогіки і психології та інклюзивної освіти

Тернопільського обласного комунального інституту післядипломної педагогічної освіти; викладач кафедри педагогіки і методики початкової та дошкільної освіти

Тернопільського національного педагогічного університету імені Володимира Гнатюка

\title{
РОЗВИТОК ІДЕЙ МЕДІАОСВІТИ В ДОШКІЛЬНИХ ЗАКЛАДАХ ТА ПОЧАТКОВИХ ШКОЛАХ УКРАЇНИ У $1985-1991$ pp.
}

У статті охарактеризовано генезу ідей медіаосвіти в дошкільних закладах та початкових школах Украйни у 1985-1991 рр. у контексті розвитку освітньої галузі, на тлі впливу суспільно-політичних чинників. Термін “медіаосвіта" на той час не використовувався. Існували прочеси, щзо зараз трактуються як медіаосвіта. Показано унікальність, суперечливість тенденцій досліджуваного періоду. Відображено початок комп 'ютеризачї̈ дошкільної та початкової освіти. Розглянуто особливості формування критичного мислення. Виявлено перспективний досвід.

Ключові слова: розвиток медіаосвіти; комп 'ютерні засоби; традиційні та інноваційні медіа; критичне мислення; дошкільні заклади; початкові школи.

Jim. 20.

Iryna Kuzma, Ph. D.(Pedagogy), Lecturer of the Pedagogy and Psychology and Inclusive Education Department Ternopil Regional Municipal Institute of Postgraduate Pedagogical Education; Lecturer of the Pedagogy and Methods of Primary and Preschool Education Department Ternopil Volodymyr Hnatiuk National Pedagogical University

\section{DEVELOPMENT OF MEDIA EDUCATION IDEAS AT PRESCHOOL INSTITUTIONS AND PRIMARY SCHOOLS OF UKRAINE IN 1985-1991}

The genesis of media education ideas at preschool institutions and primary schools of Ukraine in 1985-1991 in the context of the development of the educational sector, against the background of socio-political factors influence has been described in the article. It has been emphasized that the term "media education" was not used in the analyzed period. There were processes that now are interpreted as media education.

The beginning of computerization of preschool and primary education, didactic functions of new means, and organization of scientific researches are comprehensively characterized in the asrticle. The goals of the use of computer equipment have been outlined: training children to the "computer operating background", which will help in the future to avoid a kind of psychological barrier, prejudice against the computer; using the capabilities of computer equipment to improve the effectiveness of preparation to training. New didactic possibilities of the computer, in particular visualization, individualization, possession of huge informative potential, etc., have been defined.

It has been found that the idea of the need to study the computer from an early age and develop the ability to use its potential was widespread in the media. It has been shown that against the background of technical progress, computerization of education, which is the embryonic form of the future of media education, the educational process continued to retain traditional means, which now are interpreted as traditional media. The role of television (cartoons), radio as a means of harmonious development of children remained.

The uniqueness and contradiction of tendencies of the studied period are shown. Peculiarities of formation of children's critical thinking have been considered. Emphasis has been placed on the limitation, the locality of critical thinking. It has been found that, despite the "perestroika", ideological requirements have not lost their relevance.

Promising experience that needs to be implemented in the modern educational field has been revealed: formation of critical thinking for participation in the processes of social progress; differentiation of true and false messages, real and fabulous; performing tasks to find errors in media production, the use of computer means of education and the development of skills of teachers, kindergarten teachers for the use of these means.

Keywords: development of media education; computer equipment; traditional and innovative media; critical thinking; preschool institutions; primary schools. 
у 1973 р. на спільному засіданні сектору інформації ЮНЕСКО та Міжнародної ради з кіно та телебачення. Хоча $є$ й інша думка щодо часу започаткування медіаосвіти - 1959 р., коли канадський учений М. МакЛюен розробив першу навчальну програму з медіаосвіти. І вже у 1960-х рр. у Великій Британії, Канаді, Німеччині, США, Франції розпочалося активне застосування медіаосвіти в освітньому процесі. Її завдання було визначено як формування інформаційної культури людей та підготовка до життя в інформаційному суспільстві $[9,3]$.

Проте в Україні у 60-70-х рр. термін “медіаосвіта" не використовувався, натомість існували процеси, які зараз визначаються цим терміном, - застосування візуальних, аудальних, аудіовізувальних засобів в освітньому процесі закладів дошкільної, середньої та вищої освіти, виконання дітьми й молоддю творчих робіт, яке трактується як виготовлення медіапродукції, диференціація програм на якісні та неякісні тощо.

Водночас для формування медіаграмотності існували й гальмівні чинники. Критичне мислення було обмеженим, локальним: тотальна цензура, ідеологічні догми не залишали жодного шансу для того, щоб розрізняти правду й неправду в засобах масової інформації, формувати власну думку щодо реалій і перспектив країни, у якій живеш.

Особливим періодом у генезі медіаосвіти в Україні, яка входила до складу тоталітарної держави СРСР, є 1985-1991 рр. (від початку перебудови до утворення незалежної країни). Він дуже короткий - усього 6 років. Проте це унікальний період, у якому в сконцентрованому вигляді були представлені позитивні й негативні процеси, притаманні генезі медіаосвіти минулого, а також в елементарній, зародковій, формі виникали нові перспективні тенденції, що у XXI ст. (новому тисячолітті) отримали продовження.

У 1985-1991 рр. суттєва увага приділялася розвитку дошкільної та початкової освіти, зокрема використанню візуальних, аудальних, аудіовізувальних засобів у навчанні й вихованні дітей, упровадженню результатів наукових досліджень для підвищення якості освіти, іншим процесам, які зараз трактуються як медіаосвіта.

Аналіз досліджень і публікацій. Проблеми медіаосвіти, зважаючи на актуальність, є предметом численних розвідок В. Іванова, О. Волошенюк, Г. Головченка, Л. Кульчинської, Ю. Мірошниченко тощо. Генезу дошкільної та початкової освіти як чинник розвитку освітніх технологій, медіаосвіти вивчають К. Біницька, І. Улюкаєва, О. Янкович та ін. Зокрема, О. Янкович обгрунтувала періодизацію розвитку освітніх технологій у початкових школах України другої половини XX - початку XXI ст. У цій періодизації виокремлено 1985-1990 рр. як перебудовно-комп’ютеризаційний період. Науковець визначила його тенденції: перші спроби впровадження комп'ютера в освітній процес; початок наукових пошуків щодо можливостей вивчення основ інформатики дітьми; поєднання прогресивних інноваційних підходів і неприйнятних пережитків минулого [17, 24]. Зазначений період О. Янкович назвала зв'язувальною ланкою, містком між радянським тоталітарним минулим та сучасним розвитком шкільництва, демократичним прийдешнім України [17, 30].

Формування медіаграмотності дітей дошкільного та молодшого шкільного віку студіюють Т. Іванова, О. Писарчук, Г. Терещук, В. Чайка, О. Янкович [20] та ін. Інтеграцію медіаосвіти та освіти для сталого розвитку як перспективний напрям наукових пошуків, підвищення ефективності навчання відобразили I. Левчик, Т. РожкоПавлишин, А. Чайковська [18] та ін. Необхідність інтеграції педагогіки й інформатики для вдосконалення діагностики та як один зі шляхів підвищення рівня медіаграмотності учасників освітнього процесу обгрунтувала О. Янкович [16].

Досліджено історичні аспекти медіаосвіти у 1959-2018 pp. [5]. Проте потребує поглибленого вивчення ті процеси, що зараз потрактовані як медіаосвіта дітей дошкільного та молодшого шкільного віку. Саме в 1985-1991 рр. у контексті наступності з виокремленням перспективних ідей вона відображена недостатньо, що зумовило мету статті: дослідити генезу ідей медіаосвіти в закладах дошкільної та початкової освіти у 1985-1991 рр. та виявити перспективний досвід, що потребує втілення в сучасній освітній галузі.

Виклад основного матеріалу. На початку 80-х pp. ХХ ст. було здійснено декілька спроб реформувати освіту в тоталітарній державі СРСР. Найбільш вагомою подією стало затвердження “Основних напрямів реформування загальноосвітньої і професійної школи” (12 квітня 1984 р.).

"I хоча реформа перш за все стосувалася

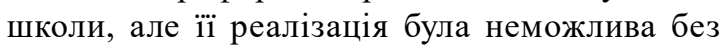
відповідної перебудови й інших ланок освітньої системи, зокрема першого і1ї ступеня дошкільного виховання", - зазначає І. Улюкаєва $[14,335]$.

Зрештою, 19 травня 1984 р. була прийнята Постанова Ради міністрів СРСР "Про дальше поліпшення суспільного дошкільного виховання і підготовку дітей до навчання в школі”, якою ініційовано низку перетворень, зокрема прийняття документів для розвитку дошкілля (“Типова 


\section{РОЗВИТОК ІДЕЙ МЕДІАОСВІТИ В ДОШКІЛЬНИХ ЗАКЛАДАХТА ПОЧАТКОВИХ ШКОЛАХ УКРАЇНИ У 1985-1991 pp.}

програма навчання та виховання дітей в дитячому садку”, “Положення про дитячий дошкільний заклад”).

Згодом педагогічні працівники зазначали, що реформа школи не виправдала багатьох сподівань освітян, проте іiї орієнтири щодо використання електронно-обчислювальної техніки, а також зарубіжні досягнення в галузі інформатизації суспільства сприяли прискоренню комп'ютеризації закладів освіти. Отже, у середині 80-х рр. у школах та навіть дитячих садках з'явився і набув поширення потужний засіб - комп'ютер, що згодом, уже в новому тисячолітті, був означений терміном "медіазасіб".

Комп’ютеризація на тлі суспільно-політичних подій (ініційована М. Горбачовим перебудова, що супроводжувалася гласністю та прискоренням економічного розвитку) зумовила виокремлення 1985 р. нижньою межею періодизацій багатьох освітніх процесів.

Отже, з 1985 р. в Україні швидкими темпами розвиваються комп’ютерні технології. Їхній генезі сприяла, окрім “Основних напрямів реформування загальноосвітньої і професійної школи” (12 квітня 1984 р.), Постанова ЦК Компартії України і Ради Міністрів Української РСР “Про дальше вдосконалення загальної середньої освіти молоді і поліпшення умов роботи загальноосвітньої школи” (№ 281 від 10 липня 1984 р. 3 подальшими змінами).

Саме 3 цього часу розпочалися системні розвідки щодо вивчення інформатики дітьми молодшого шкільного віку та доцільності використання нової техніки в дошкіллі.

Наукові пошуки проводили Інститут системних досліджень МО України, Інститут педагогіки АПН України. Учені цих установ дійшли висновку, що знайомитися 3 комп'ютерною технікою й елементами інформатики треба в ранньому дитинстві: 3 дитячого садка, перших кроків навчання в школі. У 1985-1990 рр. експериментально була доведена можливість і доцільність використання персональних комп'ютерів у процесі навчання дітей 5-9 років [6, 19]. А отже, створювалася комп'ютерна техніка, призначена спеціально для дітей, яка представлялася на виставках досягнень.

У цей період у школах та навіть дитячих садках (зазвичай відомчих, наприклад, садку ВО “Київський радіозавод”) створювалися комп’ютерні класи [10,21].

Тобто XX ст. диктувало свої вимоги щодо технізації освіти. Навіть найзапекліші песимісти зрештою визнали, що для дитячого садка це хай не завтрашній, то післязавтрашній день.
Поступово нагромаджувався й цікавий досвід спілкування дітей із комп'ютерами, було визначено психолого-педагогічні умови ефективності використання сучасної електроннообчислювальної техніки в навчанні та вихованні дітей різного віку $[8,26]$.

3'ясовано цілі використання комп'ютерної техніки: привчання дітей до “комп'ютерного операційного фону”, що допоможе в майбутньому уникнути своєрідного психологічного бар'єру, упередженості щодо комп'ютера; використання можливостей комп'ютерної техніки для підвищення ефективності підготовки до навчання $[8,26]$. Визначено нові дидактичні можливості комп'ютера, зокрема унаочнення, індивідуалізації, володіння величезним інформативним потенціалом тощо.

У 80-х - на початку 90-х рр. ХХ ст. було виявлено функцію медіазасобів у закладах дошкільної та початкової освіти, про яку зараз майже не пишуть. Ідеться про розвиток почуття гумору засобами художньої літератури, фольклорних збірок, театру $[12,12]$. Особливості української народної педагогіки, зокрема їі величезний фольклорний потенціал щодо формування щасливої, повноцінної, здорової душею й тілом дитини, вивчав В. Верховинець. У збірці “Про рухливі ігри зі співами” він зазначає, що радість, сміх, гра є головними у виховному процесі, в організації здорового способу життя малечі [2, 3-6].

На сучасному етапі використовується гуморотерапія як шлях до оздоровлення, але зазвичай лікувальна функція медіа в розвитку дітей дошкільного та молодшого шкільного віку не визначається.

У середині 80-х рр. використовується термін “комп’ютерна грамотність”: “Діти усвідомлюють, що вони охоче працюють 3 ним і успішно оволодівають початками так званої “комп’ютерної грамотності" $[8,26]$.

У засобах масової інформації поширюється думка про необхідність раннього вивчення комп'ютера та формування вміння використовувати його потенціал. При цьому як аргумент наводяться ідеї зарубіжних учених, незважаючи на те, яку країну вони представляють - соціалістичного чи капіталістичного табору.

Зокрема, Є. Маргуліс зазначає: “Провідний дослідник у галузі комп'ютерного навчання Сеймур Пейперт, учень відомого швейцарського психолога Ж. Піаже, наполягає на якомога ранішому ознайомленні дітей з комп'ютером, який може найабстрактніші речі зробити конкретними і доступними. Учений вважає, що між дітьми, які 
систематично використовують комп'ютер, і тими, хто цього не робить, утворюється розрив, який пізніше дуже важко усунути" $[8,26]$.

Крім того, Є. Маргуліс описав комп’ютери для дошкільнят: “Деякі комп’ютери, призначені для дошкільнят, - це по суті, роботи невеликого розміру, які переміщуються на аркуші паперу, малюючи пером різні лінії. Часто таким комп'ютерам надають вигляд симпатичної черепашки, і дошкільнятам залишається керувати ії рухом...” [8, 27].

У 80-х рр. ХХ ст. були здійснені суттєві кроки для забезпечення наступності дитячих садків i початкової школи, зокрема набули популярності навчально-виховні комплекси. Уже на початку 1986/1987 навчального року в Україні функціонувало понад 300 шкіл-садків із контингентом 4500 дітей [15,3].

Зрозуміло, що й використання комп'ютера в початковій школі відбувалося на вищому рівні, ніж у садках. Ішлося про розробку експериментальних курсів для учнів молодшого шкільного віку 3 початкової інформатики.

У кінці 80-х рр. були зроблені перші спроби наукового обгрунтування інформаційної технології. На думку М. Жалдака та А. Олійник, “основу нової інформаційної технології (НІТ) становлять комп'ютерна техніка, “доброзичливе” програмне забезпечення та розвинені системи комунікації. НІТ характеризують три основні властивості: інтегрованість, гнучкість, інтерактивність" $[3,72]$.

Водночас зі стрімким розвитком основ інформаційної технології в кінці 80-х рр. набула актуальності проблема підготовки вчителів до використання IКТ, а також навчання учнів основ інформатики [3, 73].

Проте реально комп'ютер у кінці 80-х рр. ще не став поширеним засобом освіти. Діти молодшого шкільного віку зазвичай його ще не бачили. Часто перші уроки з інформатики в експериментальних класах у початковій школі навіть на початку 90-х рр. розпочиналися запитаннями: “Діти, хто з Вас бачив комп’ютер?”, “Що він може виконувати?”, “З яких частин складається?" [6, 23].

У 1986 р. Міністерство освіти УРСР оголосило республіканський конкурс на створення нових навчально-наочних посібників, дидактичних ігор та іграшок із використанням комп'ютерної техніки для дошкільних закладів. Цікаво, що зразки мали відповідати певним ідеологічним, педагогічним та художньо-конструктивним вимогам $[4,31]$.

Отже, незважаючи на перебудову, ідеологічні вимоги ще не втратили актуальності. 3 використанням книг, періодики, у яких прославлялися Ленін, Жовтень, здійснювалося комуністичне виховання дітей. У цьому контексті 1985-1989 pр. нічим не відрізняються від періоду застою, облудної пропаганди. Ситуація змінилася у 1990 р., коли замість ідейного почало домінували національне виховання.

На тлі технічного прогресу, комп’ютеризації освіти, що є зародковою формою майбутнього медіаосвіти, в освітньому процесі продовжували зберігатися традиційні засоби, популярні в 60-70 pp. ХХ ст., які зараз трактуються як традиційні медіа. У закладах дошкільної та початкової освіти використовувалися екранні, звукові й екраннозвукові засоби; при цьому враховувалися програмні вимоги, вікові особливості і рівень розвитку дітей, а вчителі та вихователі підвищували педагогічну майстерність, фахову кваліфікацію наставників наймолодших $[7,16]$.

У кінці 80-х рр. зберігалася роль телебачення (мультфільмів), радіо як засобів гармонійного розвитку дітей. Декілька разів на тиждень у визначений час українське радіо зверталося до наймолодших слухачів, пропонуючи їм свої циклові передачі “Загадки їжачка-лісовичка”, “Казки Червоної Шапочки”, “Казкова хата діда Гната”, “Ярик-школярик”, “У нас в гостях журнал “Малятко”, нові вірші та казки сучасних письменників [11,31].

Медіаосвіта дітей дошкільного і молодшого шкільного віку - це частина освітнього процесу, якому притаманна трикомпонентна структура (навчання про медіа, навчання, виховання й розвиток через медіа та для медіа), що реалізується завдяки партнерству вихователів / учителів, батьків і дітей, передбачає формування вміння критичного, свідомого, відповідального сприймання інформації в усіх учасників партнерської взаємодії [5]. В освітньому процесі середини 80-х - початку 90-х рр. використовувалися друковані видання, телебачення, радіо.

Водночас зроблені перші кроки для формування критичного мислення. Його доцільно розглядати в контексті навчання для медіа.

У кінці 80-х pp. ХХ ст. дітей навчали розуміти зміст казки, співвідносити реальне і казкове $[13,12]$.

Диференціація правдивих і неправдивих повідомлень є сучасною новацією закладів початкової та дошкільної освіти. Проте основи для цих процесів закладалися ще три-чотири десятиріччя тому.

Iз середини 80-X pp. XX ст. розпочалося використання терміна “критичне мислення”, що став чи не найпоширенішим в освіті XXI ст. Уперше вчені визначили формування критичного і практичного мислення як обов'язок школи та 
дошкільного закладу. У цьому контексті С. Векслер писав: “Для розв’язання визначених партією складних завдань перебудови необхідне нове мислення. Це означає: кожному потрібне вміння бачити і негативні явища, що заважають нашому просуванню вперед, і те позитивне, що забезпечує вищі результати праці. ... Уже в дітей дошкільного віку можна закладати фундамент стереотипу нового мислення, формувати прагнення і бажання міркувати над об'єктами і явищами навколишнього світу, помічати в діях помилки, недоліки.

Спрямованість критичного мислення різна: спростувати хибні думки; вивчити позитивні і негативні сторони предметів, явищ, дій (процесу i результатів); надати допомогу, вдосконалити діяльність. Діти повинні вчитися обгрунтовувати свою оцінку" [1, 6-7]. Важливим завданням школи й садка визначено формування вміння не просто констатувати плюси і мінуси, а й пропонувати, як подолати мінуси, як піднести на вищий рівень хороше $[1,7]$.

С. Векслер пропонував виконувати завдання, які в сучасних закладах освіти трактуються як прийом “Лови помилку”: “Щоб навчити дітей знаходити і усувати помилки, їм пропонують завдання із зумисне внесеними похибками" $[1,7]$.

Аналіз формування критичного мислення дітей дошкільного та молодшого шкільного віку дає змогу зробити висновок, що воно існувало вже в кінці 80-х рр. у широкому та вузькому значенні слова: і як вишуковування помилок, і як навчання мудрості (на ці два підходи до тлумачення терміну вказує С. Терно).

Проте в кінці 80-х рр. ХХ ст. реалізація критичного мислення у двох значеннях перебувала в зародковому стані, адже політичні догми минулого ще міцно тяжіли над освітянами.

Висновки. 1985-1991 pр. (від початку перебудови до утворення незалежної України) - це період розвитку ідей медіаосвіти в закладах дошкільної та початкової освіти, який пов'язує між собою консервативне минуле (комуністична пропаганда, маніпуляції свідомістю, обмежена, локальна критика) та прогресивне прийдешнє (розквіт комп'ютерних засобів навчання, імерсивних технологій, розробка інноваційних методів критичного мислення та використання його в широкому сенсі слова як оволодіння мудрістю).

Водночас це період концентрації здобутків минулого (нарощування засобів освіти - сьогодні медіа - і їхнє різнобічне використання, проведення наукових досліджень у цій сфері, формування майстерності й готовності педагогічних працівників до застосування технічних засобів) та забезпечення генези досягнень у майбутньому.
Ідеями медіаосвіти 1985-1991 рр., що були започатковані в елементарній формі, а згодом відроджені як інноваційні, $є$ : формування критичного мислення для участі в процесах суспільного поступу; диференціація правдивих і неправдивих повідомлень, реального й казкового; виконання завдань для знаходження помилок у медіапродукції, використання комп'ютерних засобів освіти та розвиток майстерності вчителів, вихователів для їхнього застосування.

Перспективами подальших досліджень $є$ вивчення освітнього потенціалу інноваційних медіа в закладах дошкільної та початкової освіти у XXI ст.

\section{ЛІТЕРАТУРА}

1. Векслер С. Розвивати мислення дитини. Дошкільне виховання. 1988. № 9. С. 6-7.

2. Верховинець В. М. Весняночка: Ігри 3 піснями для дітей дошк. і мол. шк. віку. 5-те вид. Київ: Муз. Україна, 1989. 343 с.

3. Жалдак М. І., Олійник А. Г. Нова інформаційна технологія. Радянська школа. 1989. № 11. С. 71-73.

4. Комп'ютерна техніка - дошкільникам. Дошкільне виховання. 1986. № 3. С. 31.

5. Кузьма I. Розвиток медіаосвіти дітей дошкільного та молодшого шкільного віку (19592018 рр.). Науковий вісник Ужгородського університету. Серія: "Педагогіка. Соціальна робота”. 2020. Випуск 1 (46). С. 64-69.

6. Левшин М. М. До вивчення інформатики в 14 класах. Початкова школа. 1994. № 8. С. 19-24.

7. Максименко Л. Використання технічних засобів у навчанні та вихованні дітей педагогами дошкільного закладу № 270 м. Запоріжжя. Дошкільне виховання. 1986. № 8. С. 16-17.

8. Маргуліс Є. 3 машиною на “ти”. Дошкільне виховання. 1985. № 11. С. 26-27.

9. Медіаосвіта та медіаграмотність: короткий огляд / Іванов В., Волошенюк О., Кульчинська Л., Іванова Т., Мірошниченко Ю. 2-ге вид., стер. Київ: АУП, ЦВП, 2012. 58 с.

10. Молачова В. 3 дисплеєм на ти. Дошкільне виховання. 1988. № 7. С. 21.

11. Радіо - малятам. Дошкільне виховання. 1987. № 2. С. 31 .

12. Самсонюк Н., Сагарда М. Сміх-це потреба. Дошкільне виховання. 1991. № 6. С. 12-13.

13. Середня група: планування занять. Орієнтовний розподіл програмного матеріалу, який реалізується в другому кварталі. Дошкільне виховання. 1987. № 9. С. 10-17.

14. Улюкаєва І. Г. Розвиток дошкільної освіти в Україні в 1960-1990 pp. Наукові записки Бердянського державного педагогічного університету. 2015. Випуск 3. С. 330-339. 
15. Хоменко I. Перебудова - справа всіх. Дочкільне виховання. 1987. № 1. С. 2-3.

16. Янкович О. Підготовка майбутніх учителів початкової школи до організації педагогічної діагностики 3 використанням інформаційних технологій. Молодь і ринок. 2014. № 8. С. 7-10.

17. Янкович О. І. Розвиток освітніх технологій у початкових школах України (1959-2018 рр.): монографія. Тернопіль: Осадца Ю. В., 2021. 162 с.

18. Chaikovska H., Yankovych O., Levchyk I., Kuzma I., Rozhko-Pavlyshyn T. Formation of sustainable development competencies in primary school children. Journal of Education Culture and Society. No. 2_2021 p. 341-360. doi: 10.15503.jecs2021.2.341.360

19. Tereshchuk H. V., Kuzma I. I., Yankovych O. I., Falfushynska H. I. The formation of a successful personality of a pupil in Ukrainian primary school during media education implementation. Cloud Technologies in Education. Proceedings of the 6th Workshop CTE 2018 (Kryvyi Rih, Ukraine, December 21, 2018) / Eds. Kiv, A. E., Soloviev, V. N. CEUR-WS.org, online. P. 145-158. URL: http:// ceur-ws.org/Vol-2433/paper08.pdf(Accessed 7 Nov. 2021).

20. Yankovych O. I., Chaika V. M., Ivanova T. V., Binytska K. M., Kuzma I. I., Pysarchuk O. T., Falfushynska H. I. Technology of forming medialiteracy of children of the senior pre-school age of Ukraine. Cloud Technologies in Education. Proceedings of the 6th Workshop CTE 2018 (Kryvyi Rih, Ukraine, December 21, 2018) / Eds. Kiv, A. E., Soloviev, V. N. CEUR-WS.org, online. P. 126-144. URL: http://ceur-ws.org/Vol-2433/ paper07.pdf (Accessed 7 Nov. 2021).

\section{REFERENCES}

1. Veksler, S. (1988). Rozvyvaty myslennia dytyny [Develop the child's thinking]. Preschool Education, No. 9, pp. 6-7. [in Ukrainian].

2. Verkhovynets, V. M. (1989). Vesnianochka: Ihry z pisniamy dlia ditei doshk. i mol. shk. viku [Vesnyanochka: Games with songs for preschool and primary school age children]. Vol.5. Kyiv, 343 p. [in Ukrainian].

3. Zhaldak, M. I. \& Oliinyk, A. H. (1989). Nova informatsiina tekhnolohiia [New information technology]. Soviet School, No. 11, pp. 71-73. [in Ukrainian].

4. Kompiuterna tekhnika - doshkilnykam (1986). [Computer equipment - for preschoolers]. Preschool Education, No. 3, p. 31. [in Ukrainian].

5. Kuzma, I. (2020). Rozvytok mediaosvity ditei doshkilnoho ta molodshoho shkilnoho viku(1959-2018 rr.) [The development of media education of preschool and primary school age children (1959-2018)]. Scientific Bulletin of Uzhhorod University. Series: "Pedagogy. Social work", Vol. 1 (46), pp. 64-69. [in Ukrainian].

6. Levshyn, M. M. (1994). Do vyvchennia informatyky v 1-4 klasakh [To the study of computer science in grades 1-4]. Primary School, No. 8, pp. 19-24. [in Ukrainian].

7. Maksymenko, L. (1986). Vykorystannia tekhnichnykh zasobiv u navchanni ta vykhovanni ditei pedahohamy doshkilnoho zakladu № $270 \mathrm{~m}$. Zaporizhzhia [The use of technical means in the education and upbringing of children by kindergarten teachers of the Zaporizhia preschool institution No. 270]. Preschool Education, No. 8, pp. 16-17. [in Ukrainian].

8. Marhulis, Ye. (1985). Z mashynoiu na "ty" [With a machine on "you"]. Preschool Education, No. 11, pp. 26-27. [in Ukrainian].

9. Ivanov, V., Volosheniuk, O., Kulchynska, L., Ivanova, T. \& Miroshnychenko Yu. (2012). Mediaosvita ta mediahramotnist: korotkyi ohliad [Media education and media literacy: a brief review]. Vol. 2. Kyiv, 58 p. [in Ukrainian].

10. Molachova, V. (1988). Z dyspleiem na ty [With a display on you]. Preschool Education, No. 7, p. 21. [in Ukrainian].

11. Radio - maliatam (1987). [Radio for kids] Preschool Education, No. 2, p. 31. [in Ukrainian].

12. Samsoniuk, N. \& Saharda, M. (1991). Smikh - tse potreba [Laughter is a necessity]. Preschool Education, No. 6, pp. 12-13. [in Ukrainian].

13. Serednia hrupa: planuvannia zaniat. Oriientovnyi rozpodil prohramnoho materialu, yakyi realizuietsia v druhomu kvartali (1987). [Middle group: lesson planning. Approximate distribution of program material, which is implemented in the second quarter]. Preschool Education, No. 9, pp. 10-17. [in Ukrainian].

14. Uliukaieva, I. H. (2015). Rozvytok doshkilnoi osvity v Ukraini v 1960-1990 rr [The development of preschool education in Ukraine in 1960-1990]. Scientific notes of Berdiansk State Pedagogical University, Vol. 3, pp. 330-339. [in Ukrainian].

15. Khomenko, I. (1987). Perebudova - sprava vsikh [Perestroika is everyone's business.]. Preschool Education, No. 1, pp. 2-3. [in Ukrainian].

16. Yankovych, O. (2014). Pidhotovka maibutnikh uchyteliv pochatkovoi shkoly do orhanizatsii pedahohichnoi diahnostyky z vykorystanniam informatsiinykh tekhnolohii [Training future primary school teachers for the organization of pedagogical diagnostics with the use of information technologies]. Youth and market, No. 8, pp. 7-10. [in Ukrainian].

17. Yankovych, O. I. (2021). Rozvytok osvitnikh 
tekhnolohii u pochatkovykh shkolakh Ukrainy (19592018 rr.): monohrafiia [The development of educational technologies at primary schools of Ukraine (1959-2018): monograph]. Ternopil, 162 p. [in Ukrainian].

18. Chaikovska, H., Yankovych, O., Levchyk, I., Kuzma, I. \& Rozhko-Pavlyshyn, T. (2021). Formation of sustainable development competencies in primary school children. Journal of Education Culture and Society, No. 2, pp. 341-360. doi: 10.15503.jecs 2021.2.341.360 [in English].

19. Tereshchuk, H. V., Kuzma, I. I., Yankovych, O. I. \& Falfushynska, H. I. (2018). The formation of a successful personality of a pupil in Ukrainian primary school during media education implementation. Cloud Technologies in Education. Proceedings of the 6th
Workshop CTE 2018 (Kryvyi Rih, Ukraine, December 21, 2018) / Eds. Kiv, A. E., Soloviev, V. N. CEUR-WS.org, online, pp. 145-158. Available at: http://ceur-ws.org/Vol-2433/paper08.pdf(Accessed 7 Nov. 2021). [in English].

20. Yankovych, O. I., Chaika, V. M., Ivanova, T. V., Binytska, K. M., Kuzma, I. I., Pysarchuk, O. T. \& Falfushynska, H. I. (2018). Technology of forming medialiteracy of children of the senior pre-school age of Ukraine. Cloud Technologies in Education. Proceedings of the 6th Workshop CTE 2018 (Kryvyi Rih, Ukraine, December 21, 2018) / Eds. Kiv, A. E., Soloviev, V. N. CEUR-WS.org, online, pp. 126-144. Available at: http://ceur-ws.org/Vol2433/paper07.pdf (Accessed 7 Nov. 2021). [in English].

Стаття надійшла до редакції 27.09.2021

УДК 37.014.6:378.046-021.68

DOI:

Броніслава Ренькас, кандидат педагогічних наук, професор кафедри суспільно-гуманітарних дисииплін

Комунального закладу “Житомирський обласний інститут післядипломної педагогічної освіти” Житомирської обласної ради

\section{ОСОБЛИВОСТІ ВПРОВАДЖЕННЯ ВНУТРІШНЬОЇ СИСТЕМИ ЗАБЕЗПЕЧЕННЯ ЯКОСТІ ОСВІТИ У ЗАКЛАДІ ПІСЛЯДИПЛОМНОЇ ПЕДАГОГІЧНОЇ ОСВІТИ}

Стаття присвячена проблемі управління якістю освіти у закладі освіти, акиентовано увагу на використанні сучасних методів забезпечення якості освітньої діяльності закладу післядипломної педагогічноі освіти. Розглянуто елементи політики внутрішньої системи забезпечення якості освіти. Охарактеризовано набір прочедур впровадження системи забезпечення якості освіти у закладі післядипломної освіти.

Ключові слова: якість освіти; якість освітньої діяльності; управління якістю освіти; внутрішня система забезпечення якості освіти закладу післядипломної педагогічної освіти.

Jim. 8 .

Bronislava Renkas, Ph.D. (Pedagogy), Professor of the Social and Humanitarian Branch of Science Department of Communal Educational Institution "Zhytomyr Regional In-Service Teachers' Training Institute"

\section{PECULIARITIES OF IMPLEMENTATION OFTHE INTERNALSYSTEM OF QUALITY ASSURANCE IN EDUCATION IN THE IN-SERVICE TEACHERS'TRAINING INSTITUTE}

The article is devoted to the problem of quality management of education in an educational institution; the emphasis is on the use of modern methods of ensuring the quality of educational activities of the In-Service Teachers " Training institution. The peculiarities of education quality management as a leading idea of educational institution management are outlined.

The essence of the concepts "quality of education", "education quality management", "quality management system" is analyzed. The elements of the policy of the internal system of quality assurance of education are considered. The main principles on which the internal system of quality assurance of postgraduate pedagogical education is based as an element of policy are formulated. It is established that an essential step in understanding the policy of the internal system of quality assurance of education is to determine the purpose and main goals that the system should be guided by. The main tasks of the internal system of quality assurance of In-Service Teachers' Training institution as its intentions and orientation are outlined. Their place and role in the structure of the document, which should be the provisions of the internal quality assurance system of education in the educational institution, are determined

A set of procedures for the implementation of the system of quality assurance of In-Service Teachers'Training

(C) Б. Ренькас, 2021

146 